\title{
Biodiesel production from local isolate Penicillium commune NRC 2016
}

Azhaar, A. Hussein ${ }^{1}$. Osama, H. El Sayed ${ }^{2}$, Mohsen, S. Asker ${ }^{2}$, Saher, S. Mohamed ${ }^{2}$ and Sayeda, A. Abdelhamid ${ }^{2}$

${ }^{1}$ Botany Department, University College for Women, Arts, Science and Education, Ain Shams University

${ }^{2}$ Microbial Biotechnology Department, National Research Centre, Dokki, Cairo, Egypt

\begin{abstract}
Twenty five local filamentous fungi were screened for their abilities to produce lipids using Nile-red staining assay. Among the tested filamentous fungi, Penicillium commune NRC 2016 for biodiesel production was selected and identified based on the morphological and molecular methods. Gas chromatography (GC) analysis of lipids by this fungus showed that, the resulted fatty acids are suitable for biodiesel production. The resulted fatty acids were $20 \%$ palmitic acid, $4.65 \%$ stearic acid, $13.77 \%$ oleic acid, $32 \%$ linoleic acid, $1.75 \% \alpha-$ linolenic acid and $16.1 \%$ arachidonic acid. In conclusion, this work revealed the possibility of using the promising fungal strain P. commune NRC 2016 in biodiesel production.
\end{abstract}

\section{Key words}

Biodiesel - Penicillium commune NRC 2016 - GC analysis - Fatty acids

\section{1-Introduction}

The demand for renewable fuels has greatly increased due to limited energy resources and high oil price. Other important factors are the increased demand for energy supply and the growing concern about global warming, which is linked to the burning of fossil fuels. The use of fossil fuels accounts for about $90 \%$ of the requirement of global energy (Gavrilescu and Chisti, 2005). Economic and geopolitical restrictions on the use of oil allied to environmental concerns promoted the development of the biofuels market. Biodiesel is a biofuel produced from renewable sources, such as vegetable oil or animal fat, by the transesterification of triglycerides (TG) to form fatty acid alkyl esters (Gunstone, 2001 and Rottig et al., 2010). Biodiesel is used as a partial or full substitute for petrol diesel in unmodified combustion engines for road and waterway transport, as well as engines used for power generation (Gavrilescu and Chisti, 2005). Biodiesel fuels are increasingly attracting attention worldwide because of its environmental benefits such as biodegradability; a decrease of sulfur and aromatic hydrocarbons content, which reduce their emission during fuel combustion and lower emission of $\mathrm{CO}, \mathrm{CO}_{2}$ and particulate materials (Demirbas, 2008). Moreover, it directly influences human health by reducing $95 \%$ of cancer risk when compared with fossil diesel (Huang et al., 2010). The main sources of materials for biodiesel production are vegetable 
oils and animal fats (Hanna, 1991). Fat of animal origin often contains large amounts of free fatty acids, which make its conversion into biodiesel of good quality very difficult. Moreover, the current animal fat production is not sufficient to meet the entire need for fuel consumption (Canakci and Van Gerpen, 2001 and Demirbas, 2003). Concerns have been expressed about the competition of vegetable oil with food supply by the use of arable land (Brennan and Owende, 2010). The use of microorganisms that can be easily cultivated and yield large amounts of lipids, especially triglyceride (TG), has been regarded as one of the most promising solutions to solve the negative aspects of the production of biodiesel from agricultural or animal sources (Tao et al., 2006). Oleaginous microorganisms are defined as microbial species in which the content of lipids exceeds in $20 \%$ its dry weight (Meng et al., 2009). The biological diversity of microorganisms is remarkable and specific metabolic profiles may support lipid accumulation (Mutanda $\boldsymbol{e t}$ al., 2011). The content of oil in some microorganisms can reach up to $70 \%$ of the total cellular dry weight under appropriate culture conditions (Meng et al., 2009). Lipids accumulated in microorganisms such as fungi, bacteria, and algae are mainly in the form of triacylglycerols (TAG), used as metabolites for energy storage. Most of these lipids, which are composed of long chain fatty acids, are similar to conventional vegetable oils (Rude and Schirmer, 2009). Compared with vegetable oils and animal fats, the production of microbial oil has many advantages, such as: (i) the fastest growing, (ii) the recovery of cells to extract oil requires less work than the harvesting of oleaginous plants, (iii) no influence of environmental conditions in lipid accumulation when microbial growth is performed in closed systems (bioreactors) and (iv) easy growth in large scale (Li et al., 2008). This study concerned with studying the production of valuable biodiesel by P. commune NRC 2016, and at the same time, the harmful effects of fossil fuel in the environment will be reduced.

\section{2-Materials and Methods}

\subsection{Samples collection and fungi isolation}

Five soil samples gave codes: A, B, C, D, and E were collected in October 2014 from several districts in Egypt: Giza (2 samples), Assiut (2 samples) and El-Menia (1 sample) governorates. The sample placed in clean plastic bags and stored at $4^{\circ} \mathrm{C}$ until used. Basal medium was used for isolation and purification of oleaginous fungi according to Li et al. (2011). The typical formula was $(\mathrm{g} / \mathrm{L})$ : xylose 100.0; yeast extract $1.0 ; \mathrm{KH}_{2} \mathrm{PO}_{4} 2.0$; $\mathrm{MgSO}_{4} .7 \mathrm{H}_{2} \mathrm{O} 0.75 ; \mathrm{Na}_{2} \mathrm{HPO}_{4} 1.0 ; \mathrm{CaCl}_{2} .2 \mathrm{H}_{2} \mathrm{O} 0.2 ; \mathrm{FeCl}_{3} 0.01$, and $\mathrm{ZnCl}_{2} 0.1$ then the $\mathrm{pH}$ was adjusted at $7.0( \pm 1), 10 \mathrm{ml} / \mathrm{L}$ of Rose Bengal $(4,5,6$-Tetrachlorofluorescein) was added at concentration $50 \mathrm{mg} / \mathrm{L}$. One gram of soil particles was placed in a graduated cylinder and 50 
$\mathrm{ml}$ of the sterilized medium was added. The mixture was incubated for $24 \mathrm{~h}$. at $28^{\circ} \mathrm{C}$ under shaking (180 rpm). One milliliter of the desired dilution was transferred directly into each of sterilized agar medium cooled to just above solidifying temperature then added to petri dishes and incubated at $28^{\circ} \mathrm{C}$ for 7 days. The developing colonies were isolated and sub-cultured again until purification. For further investigation, growing fungal isolates were sub-cultured on slants of Czapek-Dox medium according to Robinson et al. (1998) as follows (g/L): glucose 30.0; $\mathrm{NaNO}_{3} 3.0 ; \mathrm{K}_{2} \mathrm{HPO}_{4} 1.0 ; \mathrm{MgSO}_{4} .7 \mathrm{H}_{2} \mathrm{O} 0.5 ; \mathrm{KCl} 0.5 ; \mathrm{FeSO}_{4} .7 \mathrm{H}_{2} \mathrm{O}$ 0.01, agar 15 , at $\mathrm{pH} 6.0( \pm 1)$ and kept in a refrigerator at $4^{\circ} \mathrm{C}$ until used.

\subsection{Screening for oleaginous fungi isolates}

\subsubsection{Qualitative screening by using Nile Red Stain}

For visualization of intracellular lipids, one $\mathrm{ml}$ of the culture broth was rinsed with $n$ hexane and then with phosphate buffered solution (PBS) (0.2 M, at pH 7). After the oil drops attached on mycelia were removed, the mycelia were used for visualization of intracellular lipids. The mycelia were mixed with $0.5 \mathrm{ml}$ PBS solution and $0.05 \mathrm{ml}$ Nile red solution at concentration $10 \mathrm{mg} / 1000 \mathrm{ml}$ acetone (Greenspan et al., 1985). According to Lim et al., (2003) the Nile red was used for staining intracellular lipid droplets after the storage of the mixture of Nile red and mycelia for $30 \mathrm{~min}$ in a dark place, stained lipid bodies were photographed using fluorescence microscope (HBO50/ac Axiostar plus, Zeiss, Jena, Germany) equipped with a CCD camera (105 colar Axiocam, Zeiss, Jena, Germany).

\subsubsection{Quantitative screening by biodiesel production}

For selection the highest lipid producer among the obtained isolates, they were cultured in a basal medium according to Abu-Elreesh and Abd-El-Haleem, (2013). The typical formula was (g/L): yeast extract $0.5 ; \mathrm{MgSO}_{4} .7 \mathrm{H}_{2} \mathrm{O} 0.4 ; \mathrm{KH}_{2} \mathrm{PO}_{4} 2.0 ; \mathrm{CaCl}_{2} 0.5 ; \mathrm{CuSO}_{4} .5 \mathrm{H}_{2} \mathrm{O}$ 0.05 and glucose 50, with initial $\mathrm{pH} 6.0( \pm 1)$ the cultures were incubated at $28^{\circ} \mathrm{C}$ for 7 days, then the fungal biomass were obtained by centrifugation using sigma 3-18 KS centrifuge (5000 $\mathrm{rpm} / 4^{\circ} \mathrm{C} / 10 \mathrm{~min}$ ) and washed three times with distilled water. Exacted weight of the biomass was taken, and frozen over night at $-80^{\circ} \mathrm{C}$. Direct transformation of frozen biomass was carried out according to the method of (Lewis et al., 2000) in a single step, $12 \mathrm{ml}$ of methanol, hydrochloric acid, and chloroform at ratio10:1:1 respectively was added to the dried fungal biomass (200 mg) in screw-cap test tube and subjected to sonication (5 min; 20 $\mathrm{kHz}$ ) to facilitate cell membrane disruption, pre-sonicated cells were suspended in the solution, vortexed and immediately placed at $90^{\circ} \mathrm{C}$ under stirring for $8 \mathrm{~h}$ in water bath at the end of reaction, the mixture was diluted with distilled water and then extracted with ethyl acetate $(100 \mathrm{ml} \times 2)$. The two immiscible layers of distilled water and ethyl acetate were 
separated using separating funnel and the ethyl acetate mixture was dried over anhydrous sodium sulfate and evaporated. The residual fatty acid methyl esters (FAMEs) were weighed to calculate the yield.

\subsection{Gas Chromatographic analysis}

Gas Chromatographic analysis for of fatty acids methyl esters (FAMEs) for the high producer isolates was performed in Central Laboratories in National Research Centre (NRC) using Agilent Technologies $6890 \mathrm{~N}$ (Net Work GC system) the USA. The oven was held at initial temperature $50^{\circ} \mathrm{C}$ and maintained for $2 \mathrm{~min}$. At rate $10,8,5,6^{\circ} \mathrm{C} / \mathrm{min}$, raised to 70,170 , 200 and $240^{\circ} \mathrm{C}$, at the rate of $2,9,5,15 \mathrm{~min}$ and run time $60.17 \mathrm{~min}$. Injector temp was held at $250^{\circ} \mathrm{C}$ splitless. A capillary column HP-5MS (5\% phenyl methyl siloxane) has a dimension of $30 \mathrm{~m} \times 320 \mu \mathrm{m}$, film thickness $0.25 \mu \mathrm{m}$. The flame ionization detector temperature was $280^{\circ} \mathrm{C}$ and the flow rate was $1.5 \mathrm{ml} / \mathrm{min}$. The carrier gas was nitrogen, with a flow rate of $30 \mathrm{ml} / \mathrm{min}$. hydrogen flow rate was $30 \mathrm{ml} / \mathrm{min}$ and air flow rate $300 \mathrm{ml} / \mathrm{min}$.

\subsection{Classical and molecular identification of the promising fungal isolate}

The promising biodiesel producer isolate $(\mathrm{C} 1)$ was identified by morphological and molecular methods.

\subsubsection{Morphological identification of the promising fungal isolate}

Identification of the isolated fungi during our investigation was carried out using the morphological characteristics as colony diameter, a color of conidia, extracellular exudates, pigmentation and the color of reverse mycelium. Microscopic features were examined also as conidial heads, fruiting bodies, the degree of sporulation, and the homogeneity characters of conidiogenous cells by optical light microscope (10×90) Olympus $\mathrm{CH} 40$ according to Ainsworth, (1971) and Pitt, (1985). Fungal isolates were grown on Czapek-Dox medium (CYA) and malt extract-agar medium (MEA) at $28^{\circ} \mathrm{C}$ for 7 days. The cultures were then kept at $4^{\circ} \mathrm{C}$.

\subsubsection{Molecular identification of the best-producing fungal isolate}

The molecular identification of the promising fungal isolate including the preparation of the fungal biomass, then extraction of fungal genomic DNA, and finally PCR amplification for fungal DNA.

\subsubsection{Preparation of the fungal biomass:}

The spores of 4 days old culture of tested fungi were collected by addition of $5 \mathrm{ml}$ sterile saline solution into the slant and the obtained suspension was inoculated into $100 \mathrm{ml}$ of Czapek Dox's medium in $250 \mathrm{ml}$ Erlenmeyer flask. After incubation at $28^{\circ} \mathrm{C}$ for 4 days, the 
cultures were filtered and the biomass was collected and washed with distilled water three times.

\subsubsection{Genomic DNA extraction}

Genomic DNA of fungi was extracted according to Sharma et al. (2007) as the following; 50 to $100 \mathrm{mg}$ fresh fungal mycelia were homogenized by mortar. Five hundred microliter of DNA extraction buffer (200 mM Tris-HCl pH 8, $240 \mathrm{mM} \mathrm{NaCl,} 25 \mathrm{mM}$ EDTA, and $1 \% \mathrm{SDS}$ ) were then added to the homogenized fungal DNA. One $\mathrm{ml}$ of phenol/ $\mathrm{CHCl}_{3}$, in the ratio of $1: 1(\mathrm{v} / \mathrm{v})$, was added and mixed gently for $10 \mathrm{~min}$ on a shaker at $(150 \mathrm{rpm})$ followed by centrifugation at $15000 \mathrm{xg}$ for $10 \mathrm{~min}$. The upper phase was transferred to a new tube and $0.1 \mathrm{ml}$ of $3 \mathrm{M}$ sodium- acetate buffer ( $\mathrm{pH} 5.2)$ and $2 \mathrm{ml}$ of ethanol (96\%) were added and mixed well, incubated for $30 \mathrm{~min}$ at $-20^{\circ} \mathrm{C}$ followed by centrifugation $\left(15000 \mathrm{xg} / 4^{\circ} \mathrm{C} / 20\right.$ min). The resulting pellets were washed with $700 \mu \mathrm{l}$ of $70 \%$ ethanol, air dried and resuspended in $100 \mu \mathrm{l}$ of sterile bi-distilled water.

\subsubsection{PCR amplification}

The primers ITS1 (5'-TCCGTAGGTGAACCTGCGG-3') and ITS4 (5'TCCTCCGCTTATTGATATGC-3') were used for the PCR. The PCR reaction was performed with 20 nanograms of genomic DNA as the template in a $30 \mu 1$ reaction mixture by using an EF-Taq (Sol Gent, Korea) as follows: Activation of Taq polymerase at $95^{\circ} \mathrm{C}$ for $2 \mathrm{~min}, 35$ cycles of $95^{\circ} \mathrm{C}$ for $1 \mathrm{~min}, 55^{\circ} \mathrm{C}$, and $72^{\circ} \mathrm{C}$ for 1 minutes each were performed, finishing with a 10 minutes step at $72^{\circ} \mathrm{C}$. The amplification products were purified with a multiscreen filter plate (Millipore Corp., Bedford, MA, USA). Sequencing reaction was performed using a PRISM Big Dye Terminator v3.1 Cycle sequencing Kit. The DNA samples containing the extension products were added to Hi-Di formamide (Applied Biosystems, Foster City, CA). The mixture was incubated at $95^{\circ} \mathrm{C}$ for $5 \mathrm{~min}$, followed by $5 \mathrm{~min}$ on ice and then analyzed by ABI Prism 3730XL DNA analyzer (Applied Biosystems, Foster City, CA).

\section{3- Results}

\subsection{Qualitative screening for fungal isolates}

The present study was carried out on 25 fungal isolates from locally soil samples collected from five locations in Egypt. The isolates were obtained using standard serial dilution technique from the original samples. The obtained results revealed that the majority of isolates were found in Assiut II while the minimum isolates were detected in Assiut I (Figure 1). 


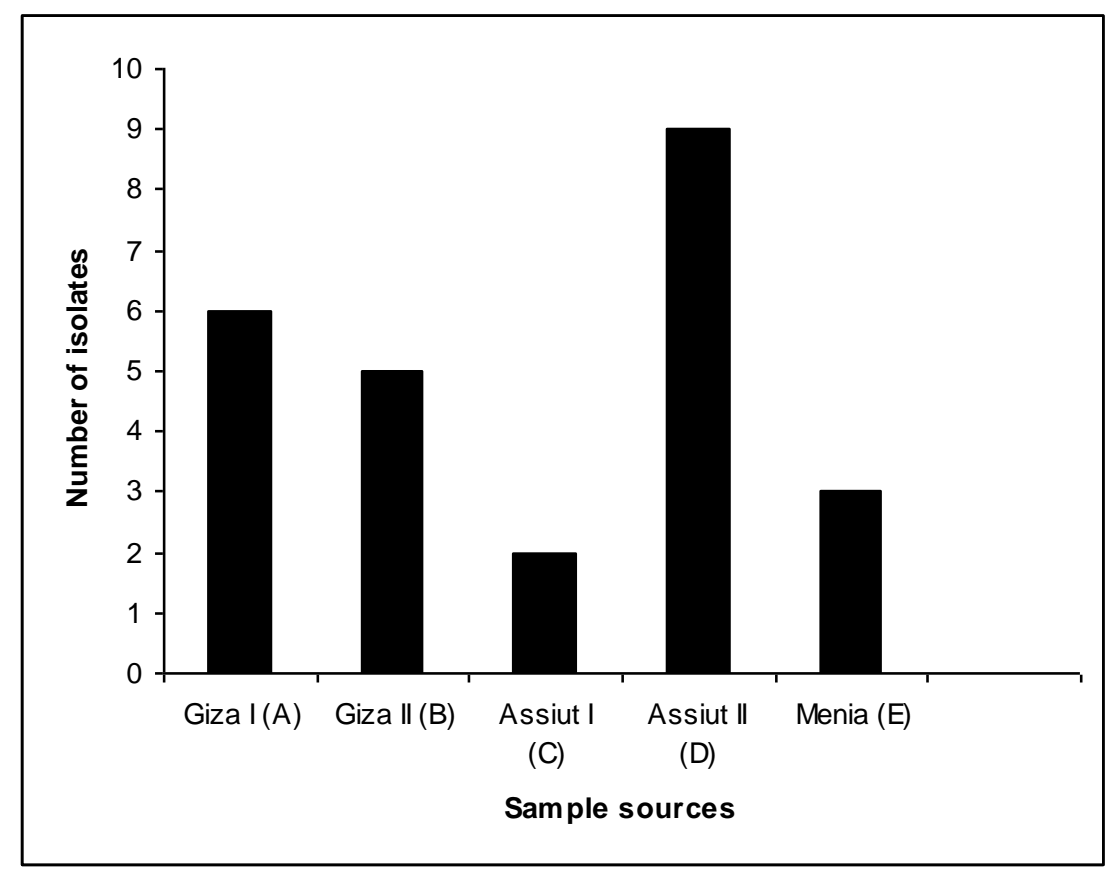

Figure (1) The number of isolated fungi from different locations in Egypt

All fungal isolates were exhibited strong fluorescence signals when using Nile-red assay. Figure (2) indicated the lipid particles under a fluorescence microscope. Nile-red viable colony staining assay was used to screen the biodiesel producers.

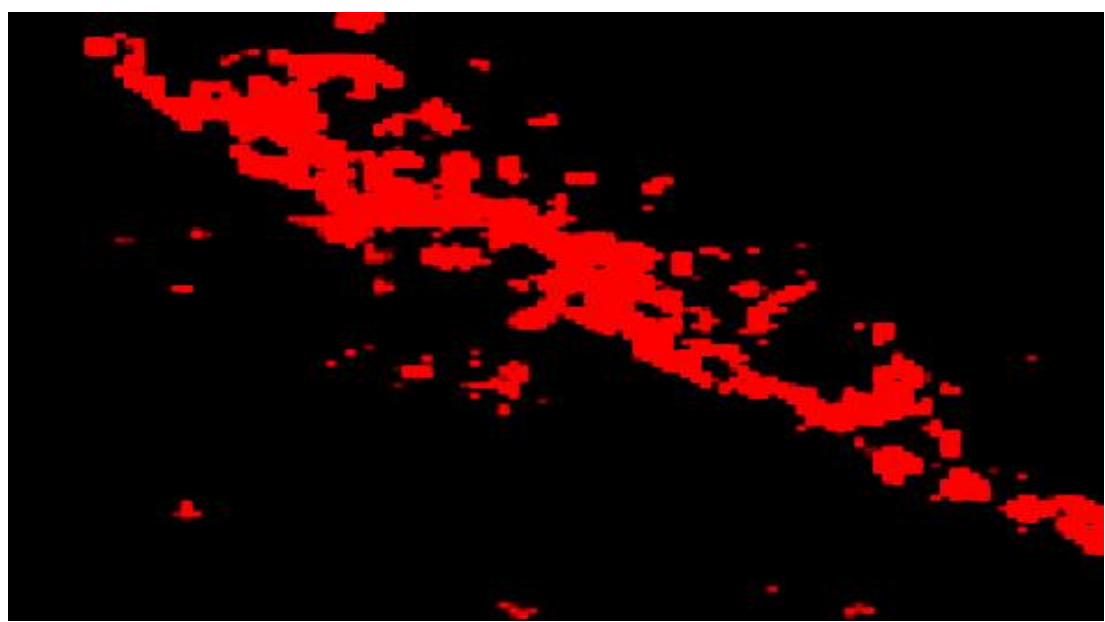

Figure (2) Fluorescence microscopy of Nile-red stained fungal strains

\subsection{Biomass and biodiesel production}

Fungal cells were grown in basal medium containing glucose and yeast extract as a carbon and nitrogen sources, respectively. Table (1) shows fungal biomass and biodiesel yield of all isolates. The highest biodiesel yield was obtained from the isolates A4, B4, C1, D10 and E1 of all locations respectively. 
Table (1) Biomass and biodiesel production of the tested fungal isolates obtained from different locations (A, B, C, D, and E)

\begin{tabular}{|c|c|c|c|}
\hline Isolates & Biomass (g/L) & Biodiesel (g/L) & Biodiesel (\%) \\
\hline A1 & 2.384 & 0.188 & 7.880 \\
\hline A2 & 1.460 & 0.100 & 6.800 \\
\hline A3 & 1.152 & 0.304 & 26.400 \\
\hline A4 & 0.568 & 0.244 & 42.950 \\
\hline A5 & 1.168 & 0.125 & 10.950 \\
\hline A6 & 4.000 & 0.108 & 2.700 \\
\hline B1 & 2.000 & 0.300 & 15.000 \\
\hline B2 & 0.400 & 0.012 & 3.000 \\
\hline$\overline{\text { B3 }}$ & 0.200 & 0.044 & 5.000 \\
\hline B4 & 1.200 & 0.232 & 19.300 \\
\hline B5 & 1.200 & 0.160 & 13.300 \\
\hline C1 & 1.600 & 0.3568 & 22.300 \\
\hline $\mathrm{C2}$ & 2.268 & 0.168 & 7.400 \\
\hline D1 & 24.632 & 0.036 & 5.700 \\
\hline D3 & 1.248 & 0.024 & 1.900 \\
\hline D4 & 6.820 & 1.152 & 16.800 \\
\hline D6 & 1.424 & 0.044 & 3.080 \\
\hline D7 & 1.208 & 0.052 & 4.300 \\
\hline D8 & 0.868 & 0.040 & 4.600 \\
\hline D9 & 0.704 & 0.068 & 9.650 \\
\hline D10 & 0.824 & 0.260 & 31.600 \\
\hline D11 & 0.925 & 0.012 & 1.200 \\
\hline E1 & 0.800 & 0.252 & 31.500 \\
\hline E2 & 2.00 & 0.352 & 17.600 \\
\hline E3 & 2.264 & 0.148 & 6.500 \\
\hline
\end{tabular}




\subsection{Analysis of biodiesel by Gas Chromatography}

The composition of fatty acid methyl esters with the profiles which are cited for the high producer isolates for each location (A4, B4, C1, D10, and E1) was in Table (2). According to that, the best producer isolate is $\mathrm{C} 1$. The single cell oils in $\mathrm{C} 1$ were found to contain a high fraction of mono and polyunsaturated fatty acids mainly $13.8 \%$ oleic acid (C18:1), 32.1\% linoleic acid (C18:2), 1.8\% $\alpha$-linoleic acid (C18:3) and 18.4\% arachidonic acid (C20:4), and a limited percentage of saturated fatty acids mainly $19.3 \%$ palmitic acid (C16) and $4.7 \%$ stearic (C18).

Table (2) Fatty acid composition of the high producer fungal isolates for each location (A4, B4, C1, D10 and E1)

\begin{tabular}{|l|l|l|l|l|l|l|l|}
\hline \multirow{2}{*}{ Isolates } & \multicolumn{7}{|c|}{ Fatty Acid \% } \\
\cline { 2 - 8 } & $\begin{array}{c}\text { Palmitic } \\
\text { acid } \\
(\mathbf{C 1 6 : 0 )}\end{array}$ & $\begin{array}{c}\text { Palmitoleic } \\
\text { acid } \\
(\mathbf{C 1 6 : 1 )}\end{array}$ & $\begin{array}{c}\text { Stearic } \\
\text { acid } \\
(\mathbf{C 1 8 : 0})\end{array}$ & $\begin{array}{c}\text { Oleic acid } \\
(\mathbf{C 1 8 : 1 )}\end{array}$ & $\begin{array}{c}\text { Linoleic } \\
\text { acid } \\
(\mathbf{C 1 8 : 2})\end{array}$ & $\begin{array}{c}\text { Linolenic } \\
\text { acid } \\
(\mathbf{C 1 8 : 3})\end{array}$ & $\begin{array}{c}\text { Arachidonic } \\
\text { acid } \\
(\mathbf{C 2 0}: 4)\end{array}$ \\
\hline A4 & 0.0000 & 0.1285 & 0.0000 & 0.4659 & 0.0000 & 0.0724 & 0.0000 \\
\hline B4 & 0.0000 & 0.1949 & 0.0000 & 2.1503 & 0.0000 & 0.3142 & 0.0000 \\
\hline C1 & $\mathbf{1 9 . 3 3 2 3}$ & $\mathbf{0 . 0 0 0 0}$ & $\mathbf{4 . 6 5 7 2}$ & $\mathbf{1 3 . 7 7 3 0}$ & $\mathbf{3 2 . 0 8 8 7}$ & $\mathbf{1 . 7 5 6 9}$ & $\mathbf{1 8 . 3 9 6 1}$ \\
\hline D10 & 0.0000 & 2.0262 & 0.3286 & 11.1266 & 5.5675 & 3.0356 & 0.0000 \\
\hline E1 & 0.0000 & 0.8988 & 0.0000 & 6.4547 & 1.7298 & 0.0000 & 0.0000 \\
\hline
\end{tabular}

\subsection{Classical and molecular identification of the fungal isolate}

Fungal taxonomy is traditionally based on comparative morphological features and molecular identification.

\subsubsection{Morphological identification of the promising fungal isolate}

The promising isolate characteristically formed colonies of the medium size, texture velutinous to floccose, conidia bluish grey to dull green on Czapek-Dox medium (CYA), dull green on malt extract-agar MEA) media and exudates clear to pale brown and reverse usually pale, sometimes yellow or brown. Stipes finely to roughen- walled on both CYA and MEA media, 100-200 $\mu \mathrm{m}$ in long. Pencilli terverticillate, metulae 8-15 $\mu \mathrm{m}$ in long, in whorls of 2-5 phialides flask - shaped, tapering in a narrow neck 7-9 $\mu \mathrm{m}$ in long. Conidia spherical to sub spherical with smooth walled and 3-4 $\mu \mathrm{m}$ in long (Ainsworth, 1971 and Pitt, 1985) that was showed in Figure (3). 


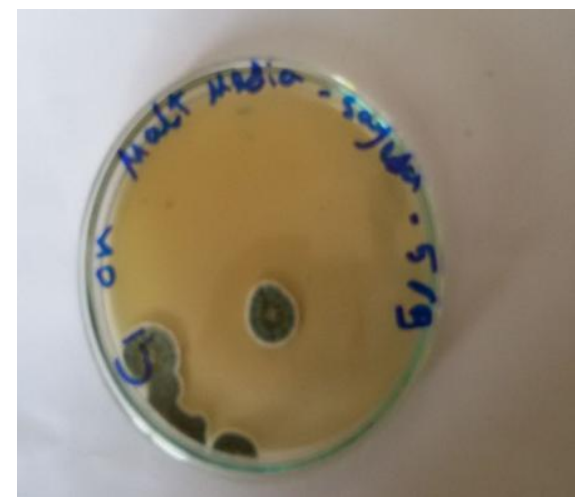

(a)

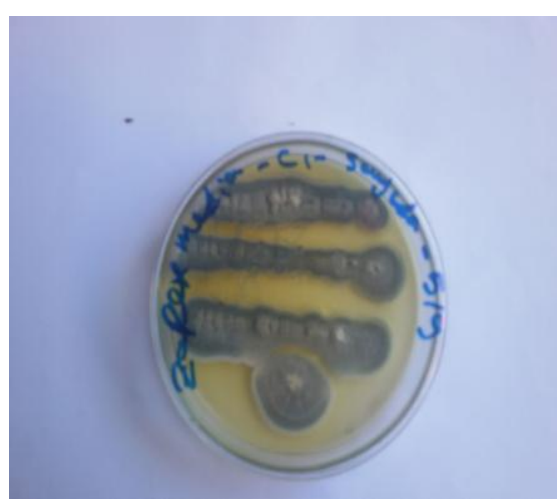

(b)

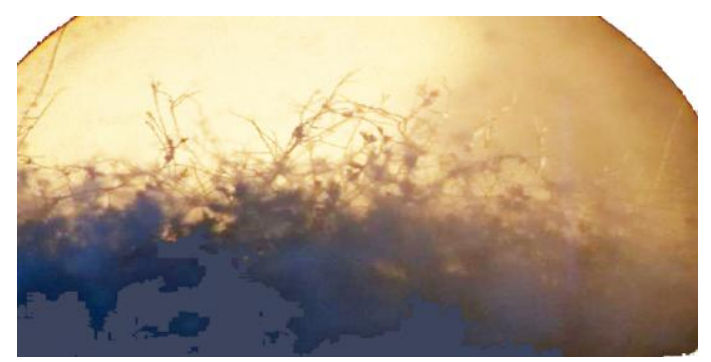

(c)

Figure (3) Morphological identification of the promising isolate ((a) Growth of the promising isolate on malt extract-agar medium, (b) Growth of the promising isolate on Czapek-Dox medium, and (c) Light microscopic phase contrast of the promising isolate)

\subsubsection{Sequencing of 18S rRNA gene of the promising isolate}

To portray the strain, the nucleotide sequences of $18 \mathrm{~S}$ rRNA of the strain were detected. The phylogenetic tree was structure by the method based on 18S rRNA sequences as showen in Figure (4). The 18S rRNA gene from the genomic DNA of the Penicillium commune NRC 2016 was enzymatically amplified by Taq DNA polymerase by using a universal fungal primer. From the phylogenetic analysis of a sequence of $P$. commune NRC 2016 with which closely related strains from the database (http://www.ncbi.nlm.nih.gov/). It appears a distinguished identity with P. commune NRC 2016. The rRNA sequence of $P$. commune NRC 2016 was deposited to Gene Bank under accession number KU752217. 


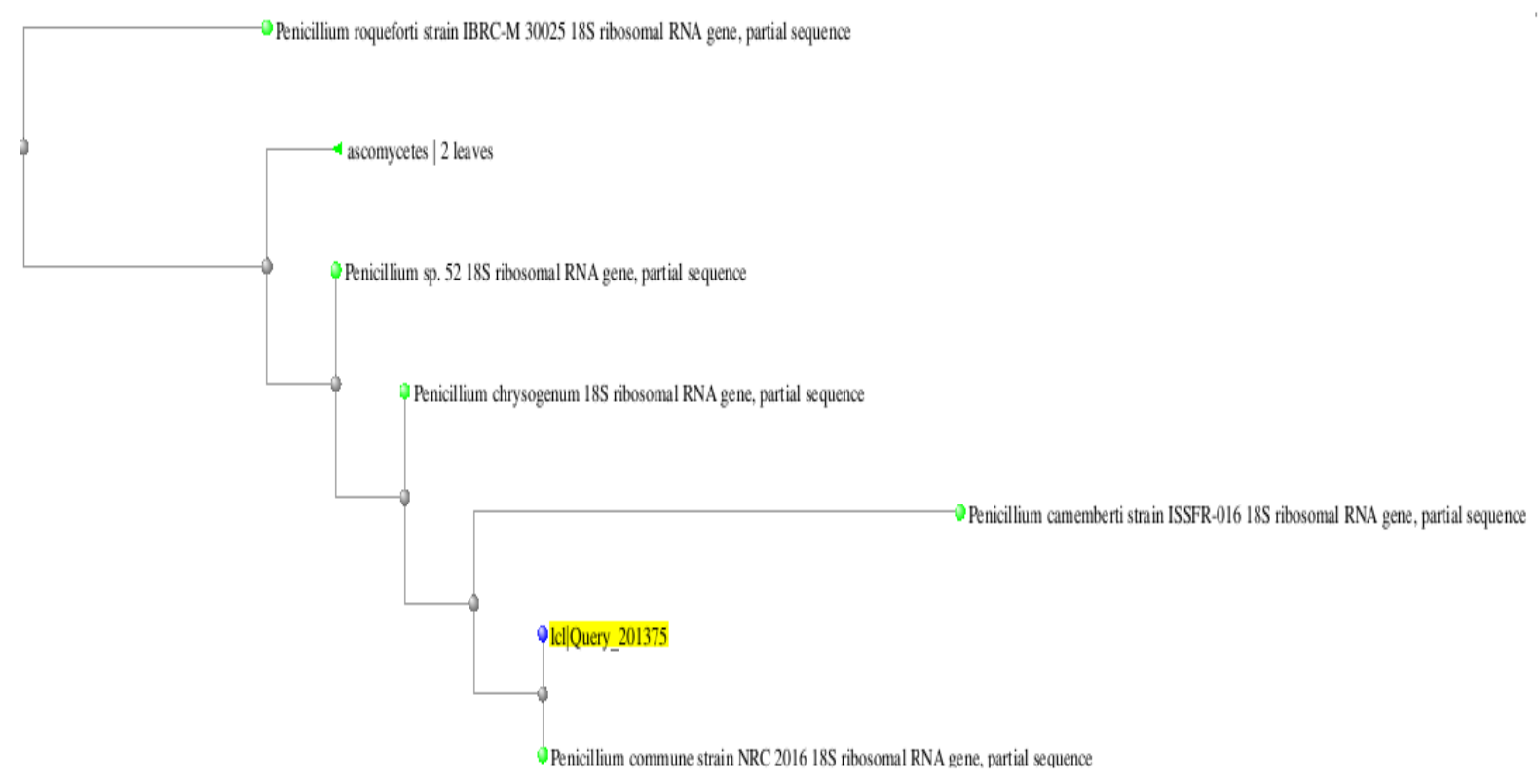

Figure (4) Phylogenetic tree showing the relationships among the selected isolate $P$. commune NRC 2016 and other closely related sequences collected from the Gene Bank

\section{Discussion}

Fungi are the most important biotechnological useful organisms (Bennett, 1999). In the present study, Nile-red staining assay was used to screen the biodiesel producers. It is known that conventional methods of lipid determination have many complicated steps that are extraction, purification, concentration, and determination. A spectrophotometer methods were safe the time consuming and Nile-red seems preferable for the intracellular lipid determination, that stain is emitting strongly positive red fluorescence signals only with hydrophobic compounds like any lipid particles inside the cells and could be detected by fluorescence spectroscopy (Lim et al., 2003 and Beopoulos et al., 2008).

Microorganisms that can accumulate oils in lipid form more than $20 \%$ of their biomass are defined as an oleaginous species, Zhu et al. (2008) and Kitcha \& Cheirsilp (2011) reported that yeast strains such as Rhodosporidium sp., Rhodotorula sp. and Lipomyces sp. can accumulate intracellular lipids from $30-70 \%$ of their biomass dry weight. In oleaginous microorganisms the carbon substrate continues to be taken up by cells and is channeled into the lipid biosynthesis pathway, increasing triacylglycerol (TAG) production and its storage in lipid bodies (Beopoulos et al., 2009, Meng et al., 2009 and Ageitos et al., 2011).

The composition of fatty acid methyl esters with the profiles which are cited in this study for the high producer isolates were in agreement with (Papanikolaou and Aggelis, 
2002, Subramaniam et al., 2010 and Fei et al., 2011) those found in plants. These include palmitic acid (C16:0), stearic acid (C18:0), oleic acid (C18:1), linoleic acid (C18:2) and linolenic acid (C18:3). According to that the best producer isolate is $\mathrm{C} 1$ that produced high content of fatty acid methyl esters, which could use in the biodiesel production while the other isolates couldn't use them. The high degree of unsaturation inherent to the FAMEs derived from the obtained fatty acids would evidence lower oxidative stability, but excellent fuel properties at low temperatures, which are an advantage in winter operation, are similar to Vicente et al. (2004).

Fungal taxonomy is traditionally based on comparative morphological features according to (Zhang $\boldsymbol{e t}$ al., 2008). However, special caution should be taken when closely related or morphologically similar endophytes are identified, because the morphological characteristics of some fungi are dependent on medium and cultural conditions can substantially affect vegetative and sexual compatibility (Zhang et al., 2006). In contrast, molecular techniques exhibit high sensitivity and specificity for identifying microorganisms and can be used for classifying microbial strains at diverse hierarchical taxonomic levels (Sette et al., 2006). Regardless of the morphological identification and depending on the molecular analysis of $18 \mathrm{~S}$ rRNA sequence of the selected fungal isolate, was identified as Penicillium commune NRC 2016 strain and was deposited to gene bank under accession number KU752217.

\section{4-Conclusion}

A promising fungal strain designated $P$. commune NRC 2016 for biodiesel production was isolated from an Egyptian soil. It was the best biodiesel productivity strain among the tested isolates. In addition, GC study revealed that the fatty acids, palmitic, oleic, linoleic and arachidonic acid were predominant in the biodiesel sample. The results suggest that $P$. commune NRC 2016 could be useful for biodiesel production.

\section{5-References}

Abu-Elreesh, G. and Abd-El-Haleem, D. An effective lipid producing fungal sp. strain DGB1 and its use for biodiesel production. African Journal of Biotechnology, 12: 5347-5353, 2013.

Ageitos, J.M.; Vallejo, J.A.; Veiga-Crespo, P. and Villa, T.G. Oily yeast as oleaginous factories. Applied Microbiology and Biotechnology, 90: 1219-1227, 2011.

Ainsworth, G.C. Ainsworth And Bisby's Dictionary of The Fungi. (Including the Lichens by P.W. James and D.L. Hawksworth), Commonwealth Mycological Institute, Kew, Surrey, England, 1971. 
Bennett, J.W. Mycotechnology: the role of fungi in biotechnology. Journal of Biotechnology, 66: 101-107, 1999.

Beopoulos, A.; Mrozova, Z.; Thevenieau, F.; Le Dall, M-T.; Hapala, I.; Papanikolaou, S.; Chardot, T. and Nicaud, J-M. Control of lipid accumulation in the yeast Yarrowia lipolytica. Applied and Environmental Microbiology, 74: 7779-7789, 2008.

Beopoulos, A.; Cescut, J.; Haddouche, R.; Uribelarrea, J.L.; Molina-Jouve, C. and Nicaud, J.M. Yarrowia lipolytica as a model for bio-oil production. Progress Lipid Research, 48: 375-387, 2009.

Brennan, L. and Owende, P. Biofuels from microalgae - a review of technologies for production, processing, and extractions of biofuels and co-products. Renewable Sustain Energy Review, 14: 557-577, 2010.

Canakci, M., and Van Gerpen, J. Biodiesel production from oils and fats with high free fatty acids. American Society Agricultural Engineering, 4:1429-1436, 2001.

Demirbas, A. Biodiesel fuels from vegetable oils via catalytic and non-catalytic supercritical alcohol transesterifications and other methods: a survey. Energy Conversion and Management, 44: 2093-2109, 2003.

Demirbas, A. Biodiesel. In: A Realistic Fuel Alternative for Diesel Engines, editor. Demirbas, A. In London: Springer, 39-64, 2008.

Fei, Q.; Chang, H.N.; Shang, L.; Choi, J.D.R.; Kim, N. and Kang, J. The effect of volatile fatty acids as a sole carbon source on lipid accumulation by Cryptococcus albidus for biodiesel production. Bioresource Technology, 102: 2695-2701, 2011.

Gavrilescu, M. and Chisti, Y. A sustainable alternative for chemical industry. Biotechnology Advances, 23: 471-499, 2005.

Greenspan, P.; Mayer, E.P. and Fowler, S.D. Nile Red: A selective fluorescent stain for intracellular lipid droplets. The Journal of Cell Biology, 100: 965-973, 1985.

Gunstone, F.D. Basic Oleochemicals, Oleochemical Products, And New Industrial Oils. In: Gunstone FD and Hamilton RJ, eds. Oleochemical Manufacture and Applications. England: Sheffield Academic Press, 1-23, 2001.

Hanna, M.A. Biodiesel production: a review. Bioresource Technology, 70: 1-15, 1991.

Huang, G.H.; Chen, F.; Wei, D.; Zhang, X.W. and Chen, G. Biodiesel production by microalgal biotechnology. Applied Energy, 87: 38-46, 2010.

Kitcha, S. and Cheirsilp, B. Screening of oleaginous yeasts and optimization for lipid production using crude glycerol as a carbon source. Energy Procedia, 9: 274-282, 2011. 
Lewis, T.; Nichols, P.D. and McMeekin, T.A. Evaluation of extraction methods for recovery of fatty acids from lipid producing micro heterotrophs. Journal of Microbiological Methods, 43: 107-116, 2000.

Li, Q.; Du, W. and Liu, D. Perspectives of microbial oils for biodiesel production. Applied Microbiology and Biotechnology, 80: 749-756, 2008.

Li, S.L.; Feng, S.L.; Li, Z.T.; Xu, H.; Yu, Y.P.; Qiao, D.R. and Ao, Y. Isolation, identification and characterization of oleaginous fungi from the soil of Qinghai Plateau that utilize D-xylose. African Journal of Microbiology Research, 5: 2075-2081, 2011.

Lim, S.H.; Ming, H.; Park, E.Y. and Choi, J.S. Improvement of riboflavin production using mineral support in the culture of Ashbya gossypii.Food Technology and Biotechnology, 41: 137-144, 2003.

Meng, X.; Yang, J.; Xu, X.; Zhang, L.; Nie, Q. and Xian, M. Biodiesel production from oleaginous microorganisms. Renewable Energy, 34: 1-5, 2009.

Mutanda, T.; Ramesh, D.; Karthikeyan, S.; Kumari, S.; Anandraj, A. and Bux, F. Bioprospecting for hyper-lipid producing microalgal strains for sustainable biofuel production. Bioresource Technology, 102: 57-70, 2011.

Papanikolaou, S. and Aggelis, G. Lipid production by Yarrowia lipolytica growing on industrial glycerol in a single-stage continuous culture. Bioresource Technology, 82: 43-49, 2002.

Pitt, J.I. A laboratory Guide to Common Penicillium species. Common Wealth Scientific And Industrial Research Organization, Division of Food Research, North Ryde, NSW. Australia, 1985.

Robinson, M.; Riov, J. and Sharon, A. Indole-3 acetic acid biosynthesis in Colletotrichum gloeosporioides F. sp.aezschynomene. Applied and Environmental Microbiology, 64: 5030-5032, 1998.

Rottig, A.; Wenning, L.; Broker, D. and Steinbuchel, A. Fatty acid alkyl esters: perspectives for production of alternative biofuels. Applied Microbiology and Biotechnology, 85: 1713-1733, 2010.

Rude, M.A. and Schirmer, A. New microbial fuels: A biotech perspective. Current Opinion in Microbiology, 12: 274-281, 2009.

Sette, L.D.; Passarini, M.R.Z.; Delarmelina, C.; Salati, F. and Duarte, M.C.T. Molecular characterization and antimicrobial activity of endophytic fungi from coffee plants. World Journal of Microbiology Biotechnology, 22: 1185-1195, 2006.

Sharma, P.; Capalash, N. and Kaur, J. An improved method for single step purification of metagenomic DNA. Molecular Biotechnology, 36: 61-63, 2007. 
Subramaniam, R.; Dufreche, S.; Zappi, M. and Bajpai, R. Microbial lipids from renewable resources: production and characterization. Journal of Industrial Microbiology and Biotechnology, 37: 1271-1287, 2010.

Tao, J.; Dai, C.C. and Dai, Q. The conversion efficiency and economic feasibility of microbial energy. Chinese Journal of Microbiology, 26: 48-54, 2006.

Vicente, G.; Martínez, M. and Aracil, J. Integrated biodiesel production: a comparison of different homogeneous catalysts systems. Bioresource Technology, 92: 297-305, 2004.

Zhang, H.W.; Song, Y.C. and Tan, R.X. Biology and chemistry of endophytes. Natural Product Reports, 23:753-771, 2006.

Zhang, Y.; Fournier, J.; Pointing, S.B. and Hyde, K.D. Are Melanomma pulvis-pyrius and Trematosphaeria pertusa congeneric? Fungal Diversity, 33: 47-60, 2008.

Zhu, L.Y.; Zong, M.H. and Wu, H. Efficient lipid production with Trichosporon fermentans and its use for biodiesel preparation. Bioresource Technology, 99: 7881-7885, 2008. 


\section{الملخص العربى}

انتاج وقود الديزل الحيوي باستخدام فطرال Penicillium commune NRC 2016

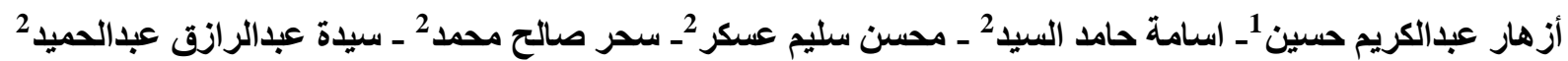

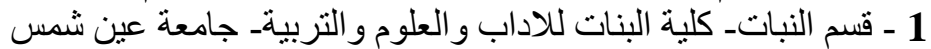
2- قسم التكنولوجيا الحيوية الميكروبية ـ شعبة الهندسة الور اثية واتية والبيوتكنولوجىـ المركز القومى للبحوث

اختبار 25 نو عامن الفطريات الخيطية المحلية وكثنف قدر اتها على إنتاج الدهون باستخدام طريقة صبغة ال -Nile red ومن خلال ذلك تم اختيار افضل فطر. و اعنمادا على كلا من التحليل المورفولوجي و التحليل البيولوجي الجزيئي تم تعريف هذا الفطر باسم 2016 Penicillium commune NRC. وبتحليل الدهون الناتجة من هذا الفطر باستخدام جهاز

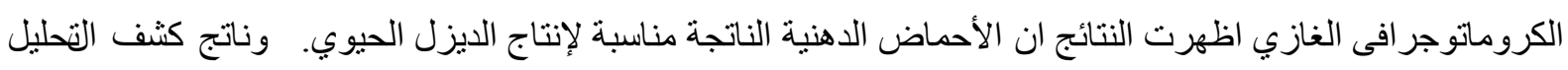

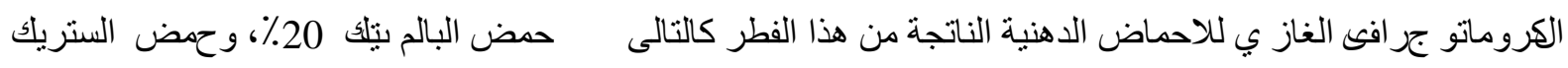
4.65٪، وحمض الأوليك 13.77٪، وحمض اللينوليك 32٪، وحمض الألفا لينولنيك 1.75٪ وحمض الأر اشبدونيك

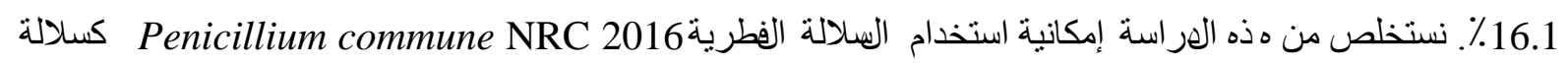

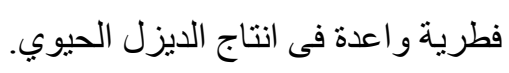

